\title{
PENDIDIKAN SEKS YANG SEHAT UNTUK ANAK-ANAK
}

\author{
Harry Suherman \\ Fakultas Psikologi Universitas Padjadjaran Bandung \\ Email: harry_hiv@yahoo.co.id
}

\begin{abstract}
Although the issue of sexual behavior has been existed for centuries but it is always interesting when it comes out in a discussion. This is understandable since sex is the human basic need and humans exist because of sex. Therefore sex and human beings are inseparable. Nevertheless, sex behavior must be controlled and with appropriate direction, especially for young generation who are living in a challenging environment. The controls for sex behavior include moral, religion, and information about healthy and responsible sex behavior. Sexual behavior is intended to build physiological, psychological, social spiritual, and procreative partnership between man and woman. The meaning of sexuality is larger than just intimate behavior between man and woman which is merely a biological interaction; it is a reflection of total human relations. Sexuality is personal relations based on commitment of love and loyalty.
\end{abstract}

Key words: Sexual, Health, Children and Adolescents, Responsibility.

Pengetahuan dan pengalaman seseorang yang berhubungan dengan masalah seks pada masa kanak-kanak berpengaruh kuat terhadap persepsi dan perilaku seksualnya pada masa dewasanya. Seseorang yang pada masa kanak-kanaknya tidak memperoleh pendidikan dan pengetahuan seks yang sehat dan bertanggung jawab cenderung akan menunjukkan perilaku seksual yang tidak sehat pada masa dewasanya. Oleh karena itu, pendidikan seks yang benar pada masa kanak-kanak menjadi sangat penting (Minor, , Muyskens, \& Alexander. 1971).

Berkaitan dengan pengetahuan tentang seks, hampir setiap orang mempunyai pandangan dan pengertian sendiri-sendiri mengenai masalah seks. Bagi sementara orang masalah seks dipandang sebagai sesuatu yang bersifat rahasia dan suci. Bagi orang yang lainnya, masalah seks mungkin diartikan sebagai sesuatu yang jorok dan menjijikkan. Bahkan, ada pula orang yang memandang seks sebagai hal yang tabu serta terlarang dan, karena itu, tidak layak untuk dibicarakan secara terbuka. Ada sebagian orang yang memandang seks sebagai sumber penderitaan, kekacauan, dan merupakan hal yang memalukan.

Yang menjadi pertanyaan adalah mengapa timbul pandangan-pandangan seperti itu? Banyak penyebabnya dan kebanyakan penyebab ini bersumber dari pengalaman masa kanak-kanak yang tidak baik yang berhubungan dengan masalah seks. Barangkali orang tua atau kakekneneknya zaman dulu menganggap perbincangan mengenai seks sebagai hal yang tabu. Akibatnya, ketika anak-anak menanyakan pada mereka tentang masalah seks, para orangtua langsung kaget dan menunjukkan sikap tertutup. Bagi orangtua semacam ini, berbincang mengenai seks adalah perbuatan yang tidak sopan. Bila anak-anaknya bertanya, maka mereka akan bersikap tertutup dengan jalan memberikan jawaban yang aneh atau yang bersifat takhayul (Minor dkk, 1971; Felomon, 1996).

Perlu diingat bahwa semakin aneh jawaban yang diterima anak-anak semakin kuat hasrat untuk mendapatkan penjelasan yang dapat memuaskannya. Jawaban anehaneh yang diterimanya, cepat atau lambat, tidak akan memuaskan rasa ingin tahu dari anak-anak tersebut. Apabila anak-anak tidak memperoleh penerangan yang baik mengenai seks, maka sulit diharapkan mereka akan mampu memberikan pendidikan seks yang baik kepada anakanaknya kelak, setelah mereka menjadi orang tua.

Mengingat gencarnya kampanye 
tentang pentingnya pendidikan seks bagi anank-anak yang harus dimulai di dalam keluarga, kini banyak orangtua yang mulai menyadari dan ingin memberikan gambaran dan pemahaman yang benar mengenai pendidikan seks kepada anak-anaknya. Akan tetapi, ketika anak-anak bertanya langsung kepada mereka, para orang tua masih sering merasa malu dan 'merah padam' wajahnya. Para orang tua memberi alasan bahwa dulu ketika mereka masih kecil masalah seks tidak pernah dibicarakan orangtua mereka di rumahnya. Sulit sekali untuk menghilangkan kesan-kesan masa kecil mereka. Oleh sebab itu, mereka tidak senang dan mungkin tidak siap untuk membicarakan masalah seks dengan anak-anaknya.

Para orang tua mungkin tidak merasa sulit untuk menceritakan kepada anakanaknya mengenai tumbuhnya tanaman, apa yang menyebabkan turunnya hujan, atau mengapa matahari terbit di ufuk Timur dan tenggelam di ufuk Barat. Akan tetapi untuk menerangkan keadaan tubuh manusia sendiri, bagaimana terjadinya manusia dan bagaimana fungsi tubuh serta organ-organ kelaminnya, banyak orang tua yang merasa sangat sulit. Hal ini dikarenakan seks adalah sesuatu yang khusus. Masalah seks erat sekali hubungannya dengan emosi dan kebutuhan seseorang. Oleh karena itu, tidak tepat bila memperbincangkannya dengan anak-anak, seperti menerangkan biologi atau ilmu alam.

Pendidikan seks tidak hanya menyangkut uraian atau penjelasanpenjelasan yang bersifat anatomis saja. Pendidikan seks bagaimanapun juga tetap akan menyangkut sifat, emosi, pandangan hidup, perilaku, kepribadian, lingkungan sosial dan nilai-nilai moral yang berlaku di dalam masyarakat (Minor dkk, 1971).

Hampir semua orang tua berkeinginan untuk memberikan suatu awal atau permulaan yang terbaik bagi kehidupan anak-anaknya. Dalam hal ini juga termasuk untuk menanamkan pengetahuan dan sifatsifat yang baik yang berhubungan dengan masalah seks, suatu hal yang akan sangat berpengaruh dalam kehidupan anak-anak kelak.

Tidak berlebihan ketika Freud
(Gunarsa \& Gunarsa, 1986) menyatakan bahwa faktor libido atau dorongan seksual merupakan faktor dominan yang memengaruhi sifat, kepribadian, dan jalan hidup individu. Pernyataan ini menunjukkan betapa pentingnya pengetahuan dan pemahaman mengenai seks yang benar ditanamkan secara dini dan wajar ke dalam benak anak-anak agar mereka dapat tumbuh dan berkembang secara layak dan wajar.

\section{PERAN PENDIDIKAN SEKS BAGI ANAK-ANAK}

Hasil penelitian Freud (Gunarsa \& Gunarsa, 1986), sebagai seorang dokter dan pemikir besar dari Austria terhadap para pasiennya, mengungkapkan adanya hubungan yang erat antara gangguan psikologis dan emosional yang dialami seseorang pada masa dewasanya dengan pengalaman seks yang tidak baik pada masa kanak-kanaknya. Gangguan psikologis yang terjadi adalah gangguan mental pada masa dewasanya yang diakibatkan oleh pengaruh masalah seksualnya. Beberapa indikasinya adalah merasa takut terhadap masalahmasalah seks, sikap dingin pada kaum perempuan, dorongan seks yang lemah pada laki-laki, homoseksualitas/lesbian dan gejala-gejala penyimpangan perilaku seksual lainnya.

Menurut Freud (Gunarsa \& Gunarsa, 1986), hal terpenting dalam pendidikan seks bukanlah memberikan keterangan yang sebanyak-banyaknya dan selengkaplengkapnya kepada anak-anak, melainkan bagaimana memberikan gambaran yang mereka bentuk dalam benak mereka tentang hubungan mereka dengan orangtuanya, hubungan antara ayah dengan ibunya dan gambaran mengenai diri mereka sendiri. Anak-anak akan berusaha menjadi seperti orangtua mereka. Mereka akan belajar untuk mengasihi, menghormati dan saling mendukung dengan pasangan hidup mereka kelak seperti yang mereka saksikan pada kedua orangtuanya.

Sebagian besar pakar pendidikan anak menekankan betapa pentingnya pendidikan seks diberikan secara dini kepada anak-anak. Mereka menegaskan bahwa adalah tanggung jawab mulia para orang tua untuk membantu 
anak-anaknya agar dapat berkembang secara sehat dan wajar, pikirannya tidak dikungkung oleh berbagai takhayul dan tabu.

Ada banyak alasan yang mendasar mengapa pendidikan seks secara dini bagi anak-anak, perlu dan penting demi kesejahteraan dan kemantapan pribadi anak setelah dewasa nanti (Abineno, 1996; Hadiwardoyo,1990). Beberapa alasan mendasar tersebut adalah:

1. Pendidikan seks secara dini akan memudahkan anak-anak menerima keberadaan tubuhnya secara menyeluruh dan akan menerima fase-fase perkembangannya secara wajar. Pendidikan ini akan membantu anak-anak untuk mampu membicarakan masalah seks dengan perasaan yang wajar.

2. Pendidikan seks yang sehat cukup efektif untuk menghilangkan rasa ingin tahu yang tidak sehat yang sering muncul dalam benak anak-anak. Anak-anak yang mengetahui kenyataan dan tahu bahwa orangtuanya mau menjawab pertanyaanpertanyaan mereka secara tuntas akan merasa tidak takut atau tidak malu-malu lagi untuk melibatkan diri dalam perbincangan mengenai seks dengan orangtuanya. Mereka tidak akan tertarik lagi dengan cerita-cerita kotor dan bahanbahan porno yang tidak mendidik.

Pendidikan seks tidak dimaksudkan untuk menghilangkan minat anak untuk mengetahui masalah seks, namun cukup efektif untuk menghambat hasrat anakanak untuk melakukan penyelidikan yang tidak terarah dan pengalamanpengalaman yang menjerumuskan.

3. Pendidikan seks yang diajarkan secara terbuka dan wajar akan membantu semangat dan gairah hidup seseorang, karena pendidikan tersebut akan membebaskannya dari persoalanpersoalan seks yang seringkali menjadi sumber ketidakbahagiaan dalam kehidupan pada saat itu maupun setelah ia menjadi dewasa (Thielicke, 1964).

Pendidikan seks yang sehat, jujur, dan terbuka juga akan menumbuhkan rasa patuh dan hormat anak-anak terhadap orangtuanya. Bila para orangtua bersikap jujur dan membantu dalam menerangkan masalah seks, maka anak-anak juga akan terdorong untuk mempercayai orangtuanya dalam hal lain, di luar masalah seks (Abineno, 1996; Hadiwardoyo, 1990).

4. Pendidikan seks kelak akan membuat anak-anak sadar dan paham akan peranannya di dalam masyarakat menurut jenis kelaminnya masing-masing. Seorang anak laki-laki akan tumbuh menjadi seorang laki-laki dewasa yang sadar akan peran dan tangung jawabnya sebagai suami atau ayah. Seorang anak perempuan akan tumbuh menjadi perempuan dewasa yang sadar akan peran dan tanggung jawabnya sebagai istri dan $\mathrm{ib}$, bagi anak-anaknya setelah ia berumah tangga. Kesadaran ini akan menumbuhkan rasa percaya diri yang cukup positif dalam jiwa anak tersebut. Hal ini juga menunjukkan bahwa pendidikan seks akan memperkuat kepribadian orang tersebut.

5. Pendidikan seks yang sehat dan wajar memungkinkan anak-anak akan mencapai taraf kedewasaan yang selaras dengan usianya. Ketika mencapai usia remaja dan usia menikah, mereka telah matang dalam mengambil keputusan yang menyangkut masa pacaran dan rencana pernikahan (Money, 1988; Seffen, 1994).

6. Pendidikan seks juga amat diperlukan untuk membangun suatu fondasi yang kokoh bagi sebuah perkawinan dan rumah tangga yang utuh dan kokoh. Para orang muda yang memasuki kehidupan perkawinan dengan berbekal pikiran yang dewasa, pengetahuan dan pengertian yang mantap serta sifat-sifat dan tindakan yang matang, dapat berharap bahwa mereka akan memperoleh kebahagiaan dalam rumah tangganya.

8. Pendidikan seks mempersiapkan seorang anak untuk kelak menjadi orang tua yang dengan baik dan benar akan mengajarkan pengetahuan seks pada anak-anaknya. Kebanyakan orang tua yang merasa sulit atau tidak mampu menerangkan masalah seks kepada anak-anaknya dibesarkan dalam lingkungan keluarga yang jarang bahkan tidak pernah membicarakan masalah seks. Boleh jadi mereka tidak memiliki pengetahuan yang baik tentang 
cara-cara mendidik anak-anaknya dalam masalah kehidupan seks.

Secara keseluruhan, informasi seks yang benar yang diberikan orang tua akan melindungi kehidupan masa depan anak dari kemungkinan-kemungkinan terjadinya penyimpangan perilaku seksualnya. Pendidikan seks ini akan mendorong anakanak untuk menumbuhkan sifat-sifat yang wajar dan sehat (Money, 1988; Seffen, 1994). Salah pengertian mengenai kehidupan seks yang tertanam pada masa kanak-kanak dapat menyebabkan terjadinya keganjilan atau kelainan, dalam pola hidup anak-anak setelah mereka tumbuh menjadi dewasa.

Selain itu, pendidikan seks yang diajarkan secara terarah dan terpimpin di dalam lingkungan keluarga cenderung cukup efektif untuk mengatasi informasi-informasi negatif yang berasal dari luar lingkungan keluarga. Misalnya, dewasa ini pornografi sudah begitu mewabah dan anak-anak juga terpapar berbagai informasi seks melalui majalah, televisi dan media lainnya. Informasi dari sumber-sumber ini seringkali tidak edukatif, bahkan cenderung lebih menonjolkan kehidupan seks yang tidak lagi mengindahkan kaidah-kaidah moral (Hadiwardoyo, 1990).

Anak-anak sering bertanya-tanya dalam hati mengenai kelahiran dan asal-usul manusia. Melalui pendidikan seks yang benar dan terarah, proses kelahiran manusia menjadi terang dan jelas. Seorang anak akan merasa bahwa memperoleh anak merupakan hal yang alamiah dan wajar apabila orangtua menerangkan kepadanya bahwa Tuhanlah yang merencanakan dan menciptakan kehidupan manusia. Keterangan ini juga cukup efektif untuk menerangkan sifat-sifat dasar religius dalam jiwa anak-anak.

Banyak orang tua yang mengalami kesulitan saat anaknya yang masih kecil merasa sulit bahkan tidak mau menerima kehadiran adik barunya. Dalam hal ini, pendidikan seks juga cukup efektif untuk membuat seorang anak dengan pengetahuannya dapat menumbuhkan sifat yang baik. Di sini orang tua mempersiapkan anaknya untuk dapat menerima dengan tenang dan gembira akan kehadiran saudara barunya. Anggota keluarga yang baru tersebut tidak lagi dianggapnya sebagai penyelundup misterius yang akan menyita perhatian kedua orang tuanya.

Bila diajarkan secara baik, pendidikan seks akan membuat anak bangga dengan jenis kelaminnya. Anak laki-laki bangga karena ia seorang laki-laki dan anak perempuan juga bangga karena ia seorang perempuan. Perasaan bangga seperti ini akan membantu anak-anak menumbuhkan sifatsifat yang layak menurut jenis kelaminnya. Selain itu, perasaan bangga ini akan menumbuhkan mereka menjadi orangtua yang wajar dan bertanggung jawab.

\section{BIJAKSANA DALAM MENDIDIK SEKS}

Banyak sekali orang tua yang merasa cemas dan ragu-ragu untuk memberikan penjelasan yang langsung dan terus terang mengenai seks kepada anak-anaknya. Jarang orang tua yang merasa bahwa pendidikan seks secara keseluruhan tidak akan mengejutkan dan membingungkan anakanak. Padahal sebenarnya orang tua tahu bahwa perilaku seks merupakan bagian dari kehidupan yang normal yang dimiliki setiap orang semenjak kelahirannya dan, karenanya, tidak perlu ditutup-tutupi secara berlebihan. Anak-anak dapat menerima informasi seks sebagai suatu keseluruhan, sebagai suatu sifat yang nyata, apabila diungkapkan secara wajar, tanpa banyak bumbu-bumbunya.

Bagi anak-anak, mengetahui kenyataan yang sebenarnya mengenai kehidupan seks jauh lebih baik daripada tidak mengetahui kenyataan tersebut dan terus menerus bertanya-tanya mengenai masalah seks.

Salah satu fakta yang perlu mendapat perhatian dari para orang tua adalah bahwa percobaan mengenai seks sering dilakukan atau terjadi pada anak-anak yang tidak memiliki pengetahuan yang baik mengenai masalah seks (Abineno, 1996; Bamforth, 1997). Pada kenyataannya, memang pengalaman atau percobaan adalah salah satu jalan untuk mendapatkan informasi atau pengetahuan. Percobaan merupakan cara yang sering dilakukan atau diterapkan anak- 
anak yang tidak memiliki pengetahuan yang baik mengenai masalah seks (Abineno, 1996; Bamforth, 1997). Pada kenyataannya, memang pengalaman atau percobaan adalah salah satu jalan untuk mendapatkan informasi atau pengetahuan. Percobaan merupakan cara yang sering dilakukan atau diterapkan anak-anak yang selalu ingin menemukan sesuatu melalui dirinya sendiri.

Anak-anak yang mempunyai pengertian yang utuh dan menyeluruh mengenai peristiwa kelahiran dan perkembangan manusia cenderung lebih mudah mengendalikan dorongan-dorongan yang bersumber dari dalam dirinya sendiri. Beberapa penelitian telah mengungkapkan bahwa para pelaku kejahatan seksual pada umumnya berasal dari keluarga-keluarga yang sama sekali tidak atau sedikit sekali memperoleh penjelasan dan pengetahuan mengenai seks dari orang tuanya.

Pendidikan seks yang baik dan benar, tidak hanya setengah-setengah, akan memuaskan rasa ingin tahu anak-anak mengenai masalah seksual. Anak-anak yang mengetahui fakta-fakta seksual dan orangtuanya bersedia membicarakan hal ini dengan mereka cenderung kurang tertarik terhadap percobaan-percobaan seksual yang tidak terarah, bila dibandingkan dengan anak-anak yang tidak mengetahui fakta-fakta dan kesadaran tersebut. Memberikan penjelasan seksual mempunyai pengaruh positif pada anak-anak. Anak-anak yang masih ingin mengajukan beberapa pertanyaan lebih suka mengajukannya secara langsung kepada orang tuanya, tidak kepada sumber-sumber yang kesadaran tanggung jawabnya atau moralitasnya masih meragukan.

Ada beberapa hal yang sangat sensitif saat orang tua memberikan pendidikan seks pada anak-anak. Terlalu banyak informasi atau penjelasan mungkin akan memberikan bahan atau pengetahuan yang terlalu luas, yang mungkin dapat berakibat cenderung menjadi negatif terhadap kepribadian anakanak tersebut (Bamforth, 1997). Tidaklah bijaksana dan juga tidak mendidik, apabila para orang tua menceritakan kepada anakanaknya segala hal yang mereka ketahui mengenai masalah seks. Anak-anak justru sering tidak dapat mengendalikan diri dan merasa terlalu dirangsang, apabila kepada mereka diberikan uraian dan informasi yang berlebihan mengenai seks tersebut.

Pada umumnya, pertanyaanpertanyaan anak-anak bersifat sederhana dan mudah. Oleh karena itu, jawabannya hanya membutuhkan keterangan atau jawaban yang juga sederhana. Mereka hanya membutuhkan jawaban atau penjelasan secara sederhana atau apa adanya atas apa yang ingin diketahuinya. Mungkin saat itu hanya itu yang menarik perhatiannya. Jujur dan sederhana adalah jawaban yang paling tepat bagi mereka (Gunarsa \& Gunarsa, 1986). Mungkin baru minggu depan atau bulan depan, anak akan bertanya kembali. Sikap yang terbaik dari orang tua adalah siap untuk menjawab pertanyaan-pertanyaan mereka, dengan memberikan jawaban sebanyak yang mereka inginkan, sesuai dengan tingkat pertumbuhan intelektualnya.

Orang tua dapat menyelamatkan anakanak dari perasaan malu yang tidak pada tempatnya atau dari pemikiran yang terlalu kritis dengan cara menegaskan kepada anakanaknya bahwa permasalahan seks sebaiknya dibicarakan di rumah saja. Orang tua dapat menerangkan kepada mereka bahwa orang tua yang lain juga ingin dan bersedia membicarakan persoalan seks ini hanya di rumah bersama anak-anaknya (Minor, dkk, 1971). Dari sana anak-anak akan mengetahui bahwa hanya orang tuanya yang mau membicarakan hal ini secara jujur dan benar. Orang dewasa yang lain mungkin tidak akan bersedia melakukannya. Anakanak tentunya akan mudah untuk menerima aturan yang sederhana ini. Lebih jauh, mereka diharapkan akan terhindar dari sumber-sumber informasi seks yang kebenaran dan moralitasnya tidak dapat dipertanggungjawabkan.

\section{USIA PENDIDIKAN SEKS}

Pada usia berapakah sebaiknya anakanak mulai memperoleh pendidikan seks? Ini merupakan salah satu pertanyaan, yang sering mengusik pikiran para orang tua. Sesungguhnya, pendidikan seks telah diberikan secara sadar atau tidak sadar oleh para orang tua kepada anak-anaknya 
semenjak hari kelahiran anak-anak tersebut. Melalui perilaku-perilaku seperti menimang, merawat, membersihkan badannya, bermain-main dengannya, juga tertawa senang bersamanya, para orang tua tanpa disadari telah mengajarkan beberapa hal penting mengenai masalah yang berhubungan dengan seks. Apabila anak ngompol, tentunya orang tua akan membersihkannya dan menggantikan popoknya. Ketika anak haus dan menangis, orang tua akan menyusuinya atau menyodorkan botol susunya. Bilamana anak lapar, orang tua akan menyuapinya dengan sabar.

Barangkali sebagian orang tua akan bertanya, apakah perilaku-perilaku tersebut merupakan bagian dari pendidikan seks juga? Jawabannya adalah ya. Perilakuperilaku tersebut merupakan bagian dari pendidikan seks, hanya terjadi secara tidak langsung. Melalui perilaku-perilaku yang menyenangkan ini sesungguhnya orang tua sedang memperkenalkan kepada anak suatu hal yang teramat penting dalam hidup ini, yaitu perasaan cinta (Minor et al, 1971; Gunarsa \& Gunarsa, 1986). Orangtua telah memberikan kepadanya awal yang baik dari perasaan hangat, pendampingan yang tulus dan ikhlas serta benih-benih kemampuan untuk menyayangi orang lain.

Kematangan pribadi orang tua, sifatsifat yang diperlihatkan dengan jelas melalui perilaku seperti mengganti popok, memandikan dan membimbing anak ke kamar mandi atau WC, ketika akan buang air, akan memperlihatkan kepada anak-anak itu bahwa masing-masing organ tubuh berfungsi secara normal. Bentuk masing-masing anggota tubuh akan mengundang minat anak kecil untuk bertanya, meskipun pertanyaannya seringkali tidak dapat dirumuskannya secara jelas. Selain itu, anakanak akan memperhatikan dan memikirkan sifat-sifat orangtuanya serta mulai mengembangkan kesadaran, perasaan dan pendapatnya sendiri, mengenai hal-hal yang mereka saksikan.

Kembali pada pertanyaan yang menjadi sub-judul topik ini, pada umur berapakah waktu yang tepat bagi anak-anak, untuk mulai mendapatkan pendidikan seks?
Pertanyaan ini sebenarnya mudah untuk dijawab. Menurut penulis, orang tua tidak harus terpaku pada usia anak untuk memberi jawaban kepada anak-anak. Hal terpenting adalah orang tua selalu menjawabnya apabila anak sudah mulai bertanya. Biasanya, anakanak mulai bertanya mengenai seks pada usia 2-4 tahun. Pada usia ini, anak-anak gemar berbicara dan merasa senang apabila pertanyaan-pertanyaannya mendapat tanggapan, meskipun sebenarnya anak sering tidak memahami arti atau maksud yang dikemukakan oleh orang tuanya.

Pada usia ini, pikirannya mulai terbuka untuk mengenali berbagai hal, tentang dunia yang terbentang luas di hadapannya, untuk anak selidiki. Anak-anak akan mulai memperhatikan perbedaan-perbedaan antara tubuhnya dengan tubuh orang lain. Pada saat ini, seringkali orangtua merasa bahwa anak kecil tidak perlu dan belum pantas mendapatkan pendidikan seks. Para orangtua berkeyakinan bahwa pendidikan seks baru akan mereka berikan, ketika anak-anak menjelang usia akil balig. Pemikiran ini merupakan pandangan yang keliru, karena sesungguhnya para orang tua secara tidak disadari telah memberikan pendidikan seks sejak kelahiran anak-anaknya tersebut.

Pada umumnya, yang menjadi masalah adalah bahwa para orang tua, tidak ingin membicarakan tentang seks dengan anakanaknya, sampai anak-anaknya mencapai usia 13 tahun. Pada usia ini, mereka anggap paling sesuai bagi anak-anaknya untuk mulai mendapatkan pendidikan seks. Tentu saja, usia 13 tahun sudah terlalu terlambat untuk mulai mendapat pendidikan seks secara sadar dari orangtua (Gunarsa \& Gunarsa, 1986). Dalam kurun waktu 0-13 tahun, beberapa peristiwa penting dalam kehidupan dan perkembangan kepribadian anak, telah terlewatkan dan mustahil dapat diulangi kembali.

Dalih atau alasan yang sering dikemukakan oleh para orang tua yang 'kolot' ini untuk menghindari menjawab pertanyaan anaknya, orang tua akan mengatakan: "Sekarang ibu/bapak tidak akan menjawab pertanyaanmu, nanti setelah kamu besar, kamu baru dapat mengerti sendiri".Jawaban seperti ini bukan 
jawaban yang bijaksana. Bila anak-anak bertanya mengenai seks, semestinya orang tua tidak menangguhkan jawabannya sampai waktu yang dianggap tepat, karena waktu yang tepat untuk menjawab pertanyaan anak adalah ketika anak itu bertanya. Apabila orang tua menangguhkannya, pertanyaan itu mungkin akan terlupakan dan daya tarik alamiah atau ingin tahu yang menimbulkan pertanyaan itu sudah berlalu.

Adakalanya, anak-anak akan mengajukan pertanyaan-pertanyaan yang agak aneh. Apabila sebagai orang tua tidak mampu menjawabnya, maka akan baik sekali bila para orang tua membahas pertanyaan itu secara jujur dan terbuka bersama anak yang bertanya tadi. Beberapa anak akan mengajukan pertanyaan yang sering dianggap terlalu dini bila dibandingkan dengan usianya. Akan tetapi, sebagai orangtua harus yakin bahwa setiap pertanyaan yang dikemukakan anak selalu dilatarbelakangi oleh rasa ingin tahu yang kuat. Jawaban yang sederhana adalah jawaban yang terbaik. Sementara penjelasan yang terlalu mendetail tidak punya pengaruh yang positif bagi anak-anak ini (Bamforth, 1997). Pertanyaan anak-anak biasanya berkisar tentang "apa" dan "bagaimana".

Seorang anak yang masih kecil tampaknya akan selalu tertarik untuk memperhatikan perbedaan-perbedaan jenis kelamin di lingkungannya sendiri. Anak melihat ayahnya tampak berbeda dengan ibunya. Apabila ia mempunyai saudara lakilaki dan perempuan, anak akan segera sadar bahwa anak laki-laki berbeda dengan anak perempuan. "Mengapa?" Ini merupakan pertanyaan yang alamiah. Suatu jawaban yang mudah dan jujur akan meyakinkan anak tersebut bahwa perbedaan-perbedaan yang dilihatnya merupakan hal yang wajar bahwa Tuhan menciptakan laki-laki berbeda dengan perempuan dan kedua-duanya adalah baik baginya.

Apabila orang tua tidak menjawab pertanyaan-pertanyaan langsung pada saat pertanyaan dikemukakan oleh anak, maka besar kemungkinan anak tersebut akan kecewa dan penasaran dan imajinasi serta pikiran anak tersebut tidak pernah berhenti. Dia mungkin akan membayangkan bahwa saudara perempuannya telah kehilangan sesuatu dari tubuhnya, sehingga tidak memiliki penis. Bila dia perempuan, mungkin ia akan merasa sedih karena ia tidak memiliki penis seperti yang dimiliki oleh saudara laki-lakinya.

Beberapa waktu kemudian, kira-kira sekitar usia 3,4 atau 5 tahun, seorang anak mungkin akan mulai ingin tahu mengenai asal usulnya. Misalnya ia bertanya "Dari manakah saya berasal?" atau "Mengapa adik/bayi bisa lahir?" Bila pertanyaanpertanyaan ini tidak terjawab, anak dapat menjadi kecewa dan penasaran. Pada masamasa berikutnya, ia mungkin sudah tidak ingat lagi bahwa ia pernah menanyakan hal ini. Akan tetapi, kekecewaannya ini akan dapat tetap berbekas sepanjang hidupnya.

Anak bertanya, orang tua yang menjawab. Apabila anak-anak mulai bertanya mengenai apa saja, terutama mengenai masalah yang berhubungan dengan seks, maka kewajiban orangtua untuk membantunya memperoleh jawaban yang memuaskan. Membiarkan anak-anak memperoleh jawaban dari orang lain atau sumber-sumber yang lain cenderung akan membuat anak-anak itu menjadi kurang percaya kepada orang tuanya (Bellamy, 2002). Dampak lebih lanjutnya adalah dapat membuat komunikasi antara anak dengan orang tua menjadi terganggu. Masalah seperti ini bila tidak segera diatasi dapat berdampak luas terhadap perkembangan kepribadian anak, antara lain dengan perkembangan harga diri (Self Esteem) anak kelak setelah mereka menginjak usia dewasa.

\section{PENUTUP}

Pelaksana pendidikan seksual yang pertama adalah orang tua. Orang tua menjadi tempat pendidikan pertama dan utama bagi anak-anaknya. Begitu juga pendidikan kepribadian, khususnya pendidikan yang menyangkut dengan kehidupan seksual. Orang tua semestinya tidak menganggap tabu untuk memperkenalkan masalah seksual kepada anak-anak sesuai dengan pertumbuhan dan perkembangan fisik, psikologis dan rohaninya. Pada zaman modern ini, dunia dipenuhi oleh eksploitasi seksual yang dapat memberikan informasi 
dan pendidikan yang keliru tentang masalah seksual kepada anak-anak muda. Jangan sampai orang tua kalah cepat oleh media atau pergaulan anak-anak di luar rumah.

Pendidikan seksual bukanlah suatu mata pelajaran mengenai seluk beluk seks atau teori-teori yang mengajarkan teknikteknik melakukan hubungan seks. Oleh karena itu, tugas untuk pendidikan seksual memang bukan semata-mata tugas guru atau tugas sekolah, bukan tugas guru biologi atau seksolog, melainkan tugas dari para orang tua di rumah. Sayangnya, masih banyak orangtua yang menganggap tabu untuk berbicara tentang seksualitas kepada anakanaknya. Padahal, banyak masalah yang dihadapi dalam hubungan orang tua dengan anak-anaknya, menyangkut juga masalah seksualitas. Yang paling penting bagi orang tua adalah untuk menyediakan waktu dan menjadi fasilitator dalam dialog-dialog mengenai masalah seks ini. Orang tua tidak sekedar mengajarkan fakta-fakta seksual, tetapi juga mengarahkannya menurut nilainilai dan norma-norma moral.

Khusus di zaman modern sekarang ini, banyak anak-anak muda yang terjerumus ke dalam masalah seks bebas, narkoba dan lainlainnya, antara lain disebabkan kurangnya perhatian orang tua kepada anak-anaknya. Dengan kata lain, diabaikannya pendidikan seksual dalam keluarga menyebabkan banyak anak muda terjerumus ke dalam penyimpangan seksualitas pada masa mudanya.

Pendidikan seksual merupakan suatu bentuk pembinaan pemahaman diri pada setiap orang yang akan memengaruhi keberadaannya sebagai laki-laki atau perempuan. Pendidikan seksual merupakan pembinaan untuk mengenali diri sebagai ciptaan Tuhan, menurut Citra-Nya. Pendidikan seks sebenarnya merupakan pendidikan kepribadian bahwa Tuhan menciptakan manusia, laki-laki dan perempuan. Laki-laki dan perempuan diciptakan secara berbeda supaya saling melengkapi, saling menolong, bermitra dalam menjalani kehidupan secara bersama.

Pendidikan seksual tidak hanya diajarkan kepada anak-anak, tetapi kepada setiap orangtua maupun muda. Bagi orang muda, supaya semakin memahami dirinya dan berpikir secara dewasa. Bagi orang tua, supaya mampu menolong anak-anak mereka (generasi muda) dalam memahami dan menerima serta memperkembangkan hidupnya, sebagaimana yang seharusnya. Selain itu, banyak juga orang tua yang mengalami penyimpangan seksual pada masa mudanya.

Pendidikan seksual bersifat multi disiplin. Artinya, mencakup pemahaman tentang manusia, baik secara biologis, psikologis, sosiologis, dan teologis. Semuanya bertujuan untuk membentuk kepribadian dan karakter yang baik, termasuk di dalam menghargai seksualitasnya. Tentu kita tidak dapat membicarakan semua faktor di sini, tetapi inilah beberapa faktor yang seharusnya menjadi isi pendidikan seksual.

Berdasarkan uraian-uraian di muka, sebenarnya sudah dapat disimpulkan bahwa tujuan pendidikan seks adalah agar sejak dini anak-anak mengenal dengan baik keberadaan dirinya, menerima dan mengembangkan pribadinya sebagai ciptaan Tuhan. Diharapkan ia akan hidup dengan menghargai dirinya, menghargai sesamanya serta menghormati Tuhan sebagai penciptanya. Dengan pola hidup menerima dan menghargai diri, sesama dan takut akan Tuhan, maka akan tercipta keluarga sejahtera, masyarakat sejahtera.

Tentunya ada tujuan khusus menyangkut pendidikan seks, yaitu supaya anak-anak dapat menghargai alat kelaminnya sebagai anugerah dari Tuhan, yang pada saatnya akan berfungsi sesuai dengan tujuan Tuhan menciptakan dan mengaruniakannya. Dalam rangka tujuan ini, orang tua tidak perlu menjelaskan seperti merumuskan dalil-dalil atau definisi, melainkan cukup dengan memberikan gambaran seperti yang telah dikemukakan, melalui dialog-dialog. Dengan sendirinya, anak-anak akan memahami tujuan percakapan atau dialog, mengenai masalah seksualitas tersebut. 


\section{DAFTAR PUSTAKA}

Abineno, J.L.Ch. (1996). Sekitar Etika dan Soal-Soal Etis. Jakarta: Gunung Mulia.

Bamforth, N. (1997). Sexuality, Moral and Justice: A Theory of Lesbian, Gay and Rights Law. London: Cassel.

Bellamy, C. (2002). World Summit for Children 2002, Document Special Session on Children.UNICEF.

Hadiwardoyo, A.P. (1990). Moral dan Masalahnya. Yogyakarta: Kanisius.

Felomon, H. (1996). Human Sexuality, Contemporary Controversies. Beverly Hills: Sagett.
Minor, H.W., Muykens, J.B, \& Alexander, M.N., (1971). Sexual Education. Richmond: Lohn Knox.

Money, J. (1988). Gay, Stright and in Between: The Sexology of Erotic Orientation. New York: Simon \& Shulster Macmillan.

Seffen, L. (1994). Life Choice: The Theory of Just Abortion. Cleveland: The Pilgrim Press.

Gunarsa, S.D. \& Gunarsa, Y.S. (1986). Psikologi Remaja. Jakarta: Gunung Mulia.

Thielicke, H. (1964). Ethics of Sex. New York: Harper \& Row Publisher. 